\title{
READERS
nsight
}

Journal of Economic Info (JEI)

ISSN:2313-3376

www.readersinsight.net/jei

\section{Trade Openness and Economic Growth: Empirical Evidence from Pakistan}

\author{
Waqas Ahmed ${ }^{*}$, Sadia Mir², Maria Siddique ${ }^{3}$, Hafiz Ur Rehman ${ }^{4}$ \\ 1,2 Higher Education Department, KPK, Pakistan \\ ${ }^{3,4}$ Department of Economics, Hazara University, Mansehra-KPK, Pakistan \\ * Corresponding author: ahmadwaqas397@yahoo.com
}

\begin{abstract}
This study examines the effects of increasing trade openness on Pakistan's economic growth. A four variable macro model based on the textbook type familiar aggregate demand - aggregate supply framework is specified. And a simple ordinary least square (OLS) technique is used for the estimation. For Pakistan, shocks to trade openness have negative (but insignificant) effects on output growth. The significance of the results depends on the specification of the model, sample size and the length of the data period. The results seem to be consistent with the findings of some empirical studies in which a country may suffer a loss due to increase openness of an economy.
\end{abstract}

Keywords: Growth; Trade Openness; Ordinary Least Square; Trade Policy
ARTICLE INFORMATION

Received: 16 November 2016

Revised: 10 January 2017

Accepted: 25 January 2017

DOI: $10.31580 /$ jei.v4i1.98

\section{INTRODUCTION}

The question of whether trade openness has positive association with economic growth has been a burning issue over the last decade. The motivation for much of this research is the "new" growth theories. The 'new' growth theories suggest that a country's trade with the rest of the world improves domestic technology and thus allows the country to grow quickly than the closed economies e.g. (Lee, 2011), (Grossman, G.M., and Helpman, 1990), and (Lucas, 1988). On the other hand the neoclassical growth theories suggest that a country's technological change is independent of the resources it possess and thus openness to world trade does not effect economic growth (Solow, 1957) among others). Despite many empirical studies there couldn't emerge consensus on the theoretical appropriateness of the new growth theories. Many empirical studies suggest strong positive effect of openness on growth (e.g. (Lee, Y.H., Ricci, A.L., and Rigobon, 2004), among others). Some studies concluded that there is negative association between the two (e.g. (Jin, 2006), among others). There are a number of reasons for this disagreement. For instance, different studies used different methodologies, openness measures, and sample countries (in case of cross country analysis).

This study investigates the relationship between trade openness and economic growth by using a four variable simple model for time series data of the economy of Pakistan. The specification is based on the framework of aggregate demand - aggregate supply analysis. Next section reviews the empirical literature on openness and economic growth. Section 3 explains the methodology used for the construction of the model and the subsequent section discusses the dataset and the construction of the variables for this paper. Whereas section 5 separately reports the examination of the estimations and results with conclusions are drawn in the last section of this paper.

\section{LITERATURE REVIEW}

The macroeconomic effect of a country's openness to international trade has been a highly debated topic in the recent literature. The motivation for much of this research is the contrast between the neoclassical growth theories and the 'new' growth theories. The neoclassical growth models, pioneered by (Solow, 1957), suggest that a country's economic progress is determined largely by a country's available resources such as capital and factor i.e. technological change is independent of its openness to world. In contrast, 'new' growth theories suggest that openness to international trade will increase growth by improving domestic technology e.g. (Lee, 2011), (Grossman, G.M., and Helpman, 1990), and (Lucas, 1988). Hence, an open economy will grow faster than a closed economy through its technological improvement.

Much research work has been done in this area. Some empirical studies confirm the new growth theories that openness to trade boosts the economic growth of a country. In a recent study, (Lee, Y.H., Ricci, A.L., and Rigobon, 2004) found that there is a strong positive association between openness and growth. The results are healthy for some specifications when openness is measured by trade over GDP ratio and even more robust when black market premium is used as proxy for openness. However, the trade aspect may be overstated because black market premium reflects other economic and policy distortions in addition to openness.

Empirical evidences vary in results about openness and growth association. Some show a strong positive association while others show small positive relation. Evidences showing negative correlation between the two are also there. Recently (Chang, R., Kaltani, L., and Loayza, 2009) empirically studied the effect of openness on growth and found that openness is correlated with faster growth, but if a country takes comprehensive measures, this positive effect can be significantly enhanced. Countries, when remove trade barriers, enjoy faster growth, and even boosted growth if they take complementary reforms.

(Chandran, R.G.V., 2009) concluded that opening of manufacturing sector of a small economy like Malaysia, to 
international trade will increase the country's economic growth; and if additional institutional measures are adopted too. They further suggest that openness should be made in that sector in which a country has comparative advantage. This survey was conducted for the manufacturing sector of Malaysia. Some similar results are obtained in a survey by (Yanikkaya, 2003). He found that trade openness positively effects economic growth, both in developed countries and developing countries. However, trade restrictions are also positively and significantly related to growth except for current account payments, which is negatively but insignificantly related to growth. However, this positive correlation depends on some characteristics of the country (i.e. whether the economy is big or small, whether it is a developed country or developing country, and whether the country has comparative advantage in those sectors that are receiving protection).

For developing countries especially, trade liberalization has been spoken to by economists as an effective policy strategy to promote economic development and economic growth. In a cross country analysis, (Lee, 2011) found that there are some characteristics of exports which can affect the node between trade and growth Countries that export high-tech products have enjoyed more rapid growth and countries that have specialized in exporting low-tech or traditional products have experienced low growth. (Greenaway, D., Morgan, W., and Wright, 2002) suggest that liberalization may affect growth of real GDP per capita favorably. Since liberalizations vary in their complexity and intensity, this is why the effects to be trailed are relatively modest.

(Harrison, 1996) found that choice of time period gives different results. For example, for cross section data analysis only one of the components of openness gives positive effect. When data is averaged over the five year period, three of the seven proxies show positive correlation between trade openness and growth; and for one year period data six of the seven components show positive association between the two.

In literature, it is also concluded that openness has effects on inflation. For price stability, many policy makers and academics have reasoned that simple feedback interest rate rule should be adopted, under which monetary authority modifies short-term interest rate in response to changes in inflation. Can these results be same for closed economy as well as for open economy? (Fiore, D.F., and Liu, 2005) found that in a closed economy, an active backward-looking interest rate rule that targets past inflation rates is more likely to guarantee local equilibrium distinctiveness than current or forward-looking interest rate rules. But this may not be a sound monetary policy for a country that is largely open to international trade.

Economies that trade less with the rest of the world are more disposed to sudden stops than those who trade more. The effect of the openness to trade on the probability of sudden stops is qualitatively strong and quantitatively significant as well. All else equal, the increase in the trade to GDP ratio by 10 percentage points will reduce the probability of sudden stop by approximately one percentage point, (e.g. (Cavallo, A.E., and Frankel, 2008).

(Jin, 2006) empirically supports the neoclassical view that a country's technological change is exogenous - unaffected by its openness to world trade. He, in his survey, conducted for the economy of Japan and Korea, concluded that increased openness to world trade has significant negative effects on the growth rates of output. He focused upon the dynamics of openness - growth and openness - inflation. Moreover, he concluded that the proxies for financial markets openness also affects output growth and inflation negatively. In his survey, he found short-run effects to be negative, while no long-run effects are found. Many studies have been undertaken and there is still no consensus on the findings. They reason is that in each study different technique is used, dataset is different, and either it is time series or cross sectional or panel data. Each study has its own type of model, i.e. their model specification is different. There is the shortcoming of the non-availability of data. Some studies have used alternative measure for openness and showed the robustness of the results. In fact, the present study tries to fill this gap.

\section{METHODOLOGY}

A four-variable model is constructed as a small macro model for Pakistan to check for short-run effects of openness on economic growth. The basis of the model specified is a familiar textbook type treatment of the framework of aggregate demand - aggregate supply. The variables of the model thus are: real GDP in 2000 prices (Y), real government expenditures in 2000 prices $(\mathrm{G})$, the broadly defined real money supply in 2000 prices (M), and the trade/GDP ratio as a proxy for openness (OPEN).

The trade/GDP ratio is used as a proxy for openness for an open economy. This ratio shows the degree of openness of a country to the rest of the world in trade. The more open a country to the world, the less the restrictions are there in international trade and the higher the share of trade in GDP. Since the data for exports and imports are easily available, most of the literature has used this ratio as a proxy for openness (e.g. (Harrison, 1996), among others). There are, however, alternative measures of openness used in some studies (e.g. (Baldwin, 2003), among others).

The model estimated for Pakistan is:

$\ln Y_{t}=\beta_{0}+\beta_{1} \ln Y_{t-1}+\beta_{2} \ln G_{t}+\beta_{3} \ln M_{t}+\beta_{4} \ln M_{t-1}+\beta_{5} O P E N_{t}+\varepsilon_{t}$

In this model we have checked for the effects of previous year GDP on current year GDP, government expenditures on GDP, current year money supply and previous year money supply effect on GDP, and the effect of openness on GDP (growth of the economy).

Simple OLS regression technique is used for the estimation because of its simplicity in using it for econometric estimation and the model is estimated over the period 1981-2010. For checking whether the model is correctly specified, we conducted the Ramsay test. In Ramsay test we check the probability of the F-statistics. And if this probability is greater than 0.1 , we reject $\mathrm{H}_{0}$ and conclude that the model is correctly specified.

The study included some macroeconomic policy variables to the model that are not directly related to international trade and may even cause a positive correlation between openness and growth. Since domestic fiscal and monetary variables are included in the model as control variables, the variables included as domestic fiscal and monetary influence aggregate demand. Real Government expenditures are used as fiscal policy variable and are deflated by the GDP deflator $(2000=100)$. M2 is used as monetary policy variable deflated by the GDP deflator $(2000=100)$. The study found this important to include Government expenditures because it can increase aggregate demand even in the absence of the effect of openness on growth. There can also be correlation between fiscal and monetary policy variables (i.e. monetizing the debt), and hence if we were to omit government spending from the model, the macro affect due to government expenditures might be incorrectly attributed to money supply.

\section{DATA AND VARIABLE CONSTRUCTION}

\section{Data}

The model employs annually data for 1981-2010 for Pakistan economy. GDP (constant 2000 US \$), imports (constant 2000 US \$), exports (constant 2000 US \$), GDP deflator $(2000=100)$, and exchange rate is obtained from WDI (produced by World Bank). Data for money supply (M2) and government expenditures is obtained from State Bank of Pakistan.

\section{Variable Construction}

The data obtained from State Bank was in nominal terms, so we converted the data to real terms by deflating it by the GDP deflator. Thus the nominal government expenditure is converted into real government expenditures, deflating by the GDP deflator $(2000=100)$. Similarly the data obtained for M2 was also in nominal terms and is made real money supply by deflating by GDP deflator $(2000=100)$. 
Moreover, the data obtained from State Bank was in local currency unit and we converted it to foreign currency unit (i.e. US \$) by multiplying each year data with the respective exchange rate. The (imports + exports)/GDP ratio is done for getting a variable as a proxy for openness. Alternative measures have also been used in the literature but data regarding those variables are not easily and correctly available. This is why we are using this measure as a proxy for openness.

\section{ESTIMATION AND RESULTS}

We employed the simple OLS estimation technique for getting the results of the effect of openness on economic growth. Table 1 presents the OLS results of the model specified. The results are shows that the effect of openness on growth is insignificant.

Table 1: Main regression analysis of the model

\begin{tabular}{lllll}
\hline Variable & Coefficient & Std. Error & t-Statistic & Prob. \\
\hline C & -0.358245 & 0.901271 & -0.397488 & 0.6947 \\
LOG(Y(-1)) & 0.977963 & 0.017322 & 56.45641 & 0.0000 \\
LOG(G) & -0.041289 & 0.024548 & -1.681947 & 0.1061 \\
LOG(M) & 0.144623 & 0.044996 & 3.214088 & 0.0038 \\
LOG(M(-1)) & -0.062425 & 0.030061 & -2.076597 & 0.0492 \\
OPEN & -0.221959 & 0.173663 & -1.278103 & 0.2140 \\
R-squared & 0.998669 & Mean dependent var & 24.86856 \\
Adjusted R- & 0.998379 & S.D. dependent var & 0.380360 \\
squared & & & \\
S.E. of & 0.015313 & Akaike info criterion & -5.338186 \\
regression & & & \\
Sum squared & 0.005394 & Schwarz criterion & -5.055297 \\
resid & & & \\
Log likelihood & 83.40369 & F-statistic & 3450.297 \\
Durbin-Watson & 1.719977 & Prob(F-statistic) & 0.000000 \\
stat & & &
\end{tabular}

stat

Dependent Variable: LOG(Y)

Method: Least Squares

The results in the above table show that there is negative association (if any) between economic growth and trade openness. The negative effect of openness on economic growth is consistent with the argument of (Batra, 1992), and (Batra, R., and Beladi, 1996). They showed that a tariff cut due to trade liberalisation policy makes foreign goods more attractive than domestic goods. This decreases the aggregate demand and ultimately economic growth decreases. The impact of lag GDP and of the government expenditures on economic growth is significant. That of the previous year GDP has robust significant effects on the economic growth. The effect of government expenditures on growth is negative. Real money supply also has significant effects on the economic growth. Money supply, when increases; decreases interest rate and private investment decreases as well. When investment decreases it adversely affects the economics growth. R-squared is showing a good fit and also t-statistics are significant except for the openness. This shows that the variables taken here in the model, correctly and almost completely explain the variations in the economic growth (i.e. $99.87 \%$ of the variation is captured by all these variables).

For model specification, we conducted Ramsey Reset test and found that the model is correctly specified. The results in table 2 show that there is specification error in the model. In Ramsay test we have two hypotheses, i.e. $\mathrm{H}_{0}=$ model correctly specified (if probability of F-statistics is greater than 0.1 ), and $\mathrm{H}_{1}=$ model not correctly specified (if probability of F-statistics is less than 0.1). Here we found that the probability is greater than 0.1 and so $\mathrm{H}_{0}$ is not rejected (showing that the model is correctly specified).

The study checked for the normality of residuals by conducting CUSUM stability test and CUSUM of squares stability test. The stability test of CUSUM for residuals clearly shows that the residuals are normally distributed. The $5 \%$ significance shows the significance of the residuals within the $5 \%$ level of significance.

\section{CONCLUSION}

The question of whether trade openness is good for economic growth has attracted the attention of policy makers since the last two decades. And enormous dynamism has been devoted to this question by academics and policy makers. Most of the evidences are based either on regression analysis or case studies. Different conclusions have been derived about the question but the question is still open. There are several reasons behind this, e.g. one reason is that there is the problem of endogeneity in the regression analysis. There is also the inconvenience of case studies to be replicated because of the different characteristics of the countries.

Some case studies show that there is strong positive correlation between growth and openness to trade, (e.g. (Yanikkaya, 2003) among others), while other shows negative association between the two (e.g. (Jin, 2006) among others).

This study investigates the relationship between trade openness and economic growth. We have used the trade/GDP ratio as proxy for openness and we found that there is no positive association between the two; rather there is insignificant negative relationship there. An alternative measure as a proxy for openness is the black market premium, used in the literature.

A four variable model using the familiar textbook type framework of aggregate demand - aggregate supply has been used. Simple "Ordinary Least Square" technique is used for the estimation purpose. And the finding is that there is negative relationship between growth and openness. When a country conducts a tariff cut policy due to trade liberalisation, it may reduce demand for domestic goods as compared to foreign goods. Since aggregate demand domestically will decrease and there will be an overall decrease in the economy's growth. Finally I stress that the domestic economy will be adversely affected if there is sudden openness of the markets for international trade; Korea's financial crisis of 1997 is an example.

\section{REFERENCES}

Baldwin, E.R., 2003. Openness and Growth: What's the empirical relationship? Natl. Bur. Econ. Res. 9578.

Batra, R., and Beladi, H., 1996. Gains from trade in a deficit-ridden economy. J. Institutional Theor. Econ. 152, 540-554.

Batra, R., 1992. The fallacy of free trade. Rev. Int. Econ. 1, 19-31.

Cavallo, A.E., and Frankel, A.J., 2008. Does openness to trade make countries more vulnerableto sudden stops, or less? Using gravity to establish causality. J. Int. Money Financ. 27, 1430-1452.

Chandran, R.G.V., and M., 2009. Trade openness and manufacturing growth in Malaysia. J. Policy Model. 31, 637-647.

Chang, R., Kaltani, L., and Loayza, V.N., 2009. Openness can be good for growth: The role of policy complementarities. J. Dev. Econ. 90, 33-49.

Fiore, D.F., and Liu, Z., 2005. Does trade openness matter for aggregate instability? J. Econ. Dyn. Control 29, 1165-1192.

Greenaway, D., Morgan, W., and Wright, P., 2002. Trade liberalisation and growth in developing countries. J. Dev. Econ. 67, 229-244.

Grossman, G.M., and Helpman, E., 1990. Trade, Innovation, and Growth. Am. Econ. Rev. 80, 86-91.

Harrison, A., 1996. Openness and growth: A time series, cross-country analysis for developing countries. J. Dev. Econ. 48, 451-472.

Jin, C.J., 2006. Can openness be an engine of sustained high growth rates and inflation?. Int. Rev. Econ. Financ. 15, 228-240.

Lee, Y.H., Ricci, A.L., and Rigobon, R., 2004. No TitleOnce again, is openness good for growth?. J. Dev. Econ. 75, 451-472.

Lee, J., 2011. Export specialization and economic growth around the world. Econ. Syst. 35, 45-63.

Lucas, E.R.J., 1988. No TitleOn the Mechanics of Economic Development. J. Monet. Econ. 22, 3-42.

Solow, M.R., 1957. Technical Change and the Aggregate Production. Rev. Econ. Stat. 39, 312-320.

Yanikkaya, H., 2003. Trade openness and economic growth: a cross-country empirical investigation. J. Dev. Econ. 72, 57-89. 